R. Soesilo, 1995, Kitab Undang-Undang Hukum Pidana: Serta Komentarkomentarnya Lengkap Pasal Demi Pasal, Politeia, Bogor

Ranuhandoko, 2003, Terminologi Hukum, Grafika, Jakarta

Sigid Riyanto, 2015, Tindak Pidana Tertentu Yang Terkait Dengan Notaris dan PPAT, Magister Kenotariatan Universitas Gadjah Mada, Yogyakarta

Syafran Sofyan, 2015, Perlindungan Hukum Profesi PPAT-Notaris, Makalah pada Seminar Nasional: Perlindungan Hukum Terhadap Notaris Lampu Merah Oleh Majelis Kehormatan Notaris di Magister Kenotariatan FH Universitas Diponegoro 6 Juni 2015, Semarang

$* * * * *$

Acta Comitas (2017) $1: 110-121$

ISSN : 2502-8960 I e-ISSN : 2502-7573

\title{
SANKSI HUKUM TERHADAP NOTARIS YANG MELANGGAR KEWAJIBAN DAN LARANGAN UNDANG-UNDANG JABATAN NOTARIS \\ Oleh
}

\author{
Mardiyah*, Prof.Dr.I Ketut Rai Setiabudhi, SH., MS.**, \\ Dr.Gde Made Swardhana, SH., MH. ***
}

Mahasiswi Program Magister Kenotariatan Universitas Udayana e-mail: nadinediyah@yahoo.com

\section{$A B S T R A C T$ \\ LEGAL SANCTIONS TO NOTARY VIOLATING OBLIGATIONS AND PROHIBITION UNDER THE LAW ON NOTARY FUNCTION.}

Law Number 2 of 2014 on Notary Function (UUJN) governs on Civil and Administrative sanctions to Notary violating obligations and prohibition as set forth in Article 16 and 17 of UUJN, however criminal sanction is not governed in the UUJN, therefore the application of criminal sanction itself has not been able to be imposed to a Notary violating the obligations and prohibitions of UUJN. And there is no arrangement to the mechanism of civil sanction imposition related to the cancellation of deed in the event of the authentic deed in the UUJN. Based on the background, the problems arising, namely, first How is the setting of legal sanctions against Notary violating Obligations and Prohibition of UUJN and second, what is the mechanism of handing down sanction (pursuant to the procedural law) to the Notary violating obligations and prohibitions UUJN how is the settlement mechanism of legal sanctions against Notary violating UUJN-P?

This study is qualified as a normative legal research. The source of legal materials for this study was obtained from primary, secondary and tertiary legal materials. The results of this thesis are civil sanction is governed in Article 16 paragraph (9 and 12), Article 41, Article 44 paragraph (5), Article 48 paragraph (3), Article 49 paragraph (4), Article 50 paragraph (5) and Article 51 paragraph (4) of UUJN. The administrative sanction is governed in Article 7 paragraph (2), Article 16 paragraph (11 and 13), Article 17 paragraph (2), Article 19 paragraph (4), Article 32 paragraph (4) Article 37 paragraph (2), Article 54 paragraph (2) and Article 65A of UUJN. Criminal sanctions are not governed, but a notary may be charged with criminal sanction pursuant to the provisions of Penal Code, providing that the act of the notary has complied with the formulation of breaches set forth in the UUJN, ethic codes and Penal Code. Second, the mechanism of application of civil sanction related to the cancellation of authentic deed into under hand deed should go through civil lawsuit process at general court lodged by the parties whose names are stipulated in the deed and suffer from damages as the effect of such deed. The mechanism of application of administrative sanctions to a notary should be directly imposed by the Supervisory Board, where the sanctions are gradually applied. The mechanism of application of criminal sanction to a notary if proved to commit the criminal act, the Notary shall be penalized and generally Penal Code can be applied to the Notary pursuant to the principle of lex spcialist derogate legi generali interpreted in a contrario manner.

Key words: legal sanction, obligation, notary prohibition.

* Mahasiswa Program Studi Kenotariatan T.A 2014/2015.

**Pembimbing I

$* * *$ Pembimbing II 


\section{Pendahuluan}

\subsection{Latar Belakang Masalah}

Notaris sebagai manusia biasa, dalam menjalankan tugas jabatannya dapat melakukan kesalahan atau pelanggaran. Notaris yang terbukti melakukan pelanggaran terhadap kewajiban dan larangan Notaris sebagaimana diatur dalam Pasal 16 dan 17 UUJN, dapat dikenakan sanksi baik berupa sanksi perdata, sanksi administratif, sanksi kode etik bahkan sanksi pidana .' Sanksi perdata umumnya merupakan sanksi yang diberikan atas pelanggaran hukum privat, yaitu hukum yang mengatur hubungan antar pribadi dalam memenuhi

kepentingan-kepentingannya. ${ }^{2}$ Sanksi

administratif merupakan sanksi yang timbul dari hubungan antara pemerintah (melalui lembaga yang berwenang) dan warganya. Tanpa perantara seorang hakim, sanksi itu dapat langsung dijatuhkan oleh pemerintah. ${ }^{3}$ Sanksi kode etik dapat dijatuhkan terhadap Notaris yang melakukan pelanggaran terhadap kode etik jabatan Notaris. Sanksi tersebut dijatuhkan oleh Majelis Kehormatan Notaris. Adapun sanksi pidana karena tidak diatur dalam UUJN, maka sanksi pidana akan dikenakan jika Notaris dalam menjalankan tugas jabatannya telah memenuhi unsur-unsur delik tertentu suatu tindak pidana berdasarkan Kitab UndangUndang Hukum Pidana (KUHP). ${ }^{4}$

UUJN mengklasifikasikan empat jenis sanksi administratif yang dijatuhkan terhadap pelanggaran beberapa pasal yang disebutkan secara limitatif yaitu berupa peringatan tertulis, pemberhentian sementara, pemberhentian dengan hormat dan pemberhentian dengan tidak hormat. Penjatuhan sanksi-sanksi administratif dilakukan hanya apabila terbukti melanggar

${ }^{1}$ Putri A.R. 2011, Perlindungan Hukum Terhadap Notaris (Indikator Tugas-Tugas Jabatan Notaris yang Berimplikasi Perbuatan Pidana), PT. Softmedia, Jakarta, h.9-10.

${ }^{2}$ Soerjono Soekanto dan Purnadi Purbacaraka, 1993, Sendi-Sendi Ilmu Hukum dan Tata Hukum, Citra Aditya Bakti, Bandung, h.63.

${ }^{3}$ Jan Remmelink, 2003, Hukum Pidana, Komentar atas Pasal-Pasal Terpenting dari Kitab Undang-Undang Hukum Belanda dan Padanannya dalam Kitab Undang-Undang Hukum Pidana Indonesia, Gramedia Pustaka Utama, Jakarta, h.15.

${ }^{4}$ Pasal 63 ayat (2) KUHP menyebutkan: "Apabila ada suatu perbuatan yang dapat dipidana menurut ketentuan pidana yang khusus disamping pidana yang umum, maka ketentuan pidana yang khusus itulah yang dipakai, sebaliknya apabila ketentuan pidana khusus tidak mengatur, maka terhadap pelanggaran tersebut akan dikenakan pidana umum yaitu KUHP”. ketentuan Pasal 7 ayat (1), Pasal 16 ayat (1) huruf a sampai dengan huruf 1 , Pasal 16 ayat (13), Pasal 17 ayat (1), Pasal 19 ayat (2), Pasal 32 ayat (1, 2, dan 3), Pasal 37 ayat (1) dan Pasal 54 ayat (1) UUJN.

Sanksi perdata umumnya merupakan sanksi yang diberikan atas pelanggaran hukum perdata. Tindakan pelanggaran yang dilakukan Notaris terkait sanksi perdata menyebutkan bahwa:

Tindakan pelanggaran yang dilakukan oleh Notaris terhadap ketentuan sebagaimana dimaksud dalam Pasal 16 ayat (1) huruf m, ayat (7) dan ayat (8), Pasal 41 yang menunjuk Pasal 38, Pasal 39 dan Pasal 40, Pasal 44 ayat (1) sampai ayat (4), Pasal 48 ayat (1) dan ayat (2), Pasal 49 ayat (1) dan ayat (2), Pasal 50 ayat (1) sampai ayat (4) dan Pasal 51 ayat (2) yang mengakibatkan suatu akta hanya mempunyai kekuatan pembuktian sebagai akta di bawah tangan dan dapat menjadi alasan bagi pihak yang menderita kerugian untuk menuntut penggantian biaya, ganti rugi dan bunga kepada Notaris.

Penting dicermati pengaturan sanksi perdata terhadap Notaris karena melanggar pasal - pasal di atas dan mengakibatkan suatu akta akan terdegradasi sehingga hanya mempunyai kekuatan pembuktian sebagai akta di bawah tangan dan dapat menjadi alasan bagi pihak yang menderita kerugian untuk menuntut penggantian biaya, ganti rugi, dan bunga kepada Notaris.

Istilah degradasi mempunyai arti penurunan mutu atau kemunduran atau kemerosotan status, dalam arti posisinya lebih rendah dalam kekuatan sebagai alat bukti, dari kekuatan bukti lengkap dan sempurna menjadi permulaan pembuktian seperti akta di bawah tangan dan dapat memiliki cacat hukum yang menyebabkan kebatalan atau ketidakabsahannya akta tersebut. ${ }^{5}$ Pelaksanaan turunnya kekuatan pembuktian akta hanya karena kurang paraf, (Pasal 50 ayat (2) UUJN) yang salah satu akibatnya berpengaruh pada perjanjian kredit apabila debitur wanprestasi, kemudian Notaris harus mengganti kerugian berikut bunga dan biaya-biaya yang timbul. Apabila ada pihak debitur yang beritikad tidak baik, hal-hal tersebut dapat menjadi celah hukum untuk menjatuhkan sanksi kepada Notaris tanpa perlu dibuktikan terlebih dahulu. Disisi lain, hal ini dapat membuka kemungkinan interpretasi bahwa pembuktian terhadap akta Notaris yang terdegradasi kekuatan pembuktiannya menjadi akta di bawah tangan dapat dilakukan secara sepihak tanpa harus melalui proses gugatan ke pengadilan.

${ }^{5}$ R. Subekti, 2008, Hukum Pembuktian, Pradnya Paramita, Jakarta, h.27. 
Sanksi Pidana terhadap Notaris tunduk terhadap ketentuan pidana umum, yaitu KUHP. UUJN tidak mengatur mengenai penjatuhan sanksi pidana terhadap Notaris. Tidak dijatuhkannya sanksi pidana terhadap Notaris yang melakukan pelanggaran terhadap kewajiban dan larangan Notaris, disebabkan dalam peraturan UUJN dan Kode etik Notaris tidak mengaturnya. Selain itu Notaris yang dijatuhi pidana dianggap hanya melakukan pelanggaran kecil, sehingga hanya dijatuhi sanksi berupa sanksi perdata atau ganti rugi ataupun sanksi administrasi atau hanya berupa teguran. Namun dalam praktek, Notaris dalam melakukan suatu pelanggaran UUJN, sebenarnya dapat dijatuhi sanksi administrasi atau perdata atau kode etik jabatan Notaris, tapi kemudian ditarik atau dikualifikasikan sebagai suatu tindak pidana yang dilakukan oleh Notaris. Aspek-aspek tersebut merupakan batasan-batasan yang jika dapat dibuktikan dapat dijadikan dasar untuk dijatuhkan sanksi administratif dan sanksi perdata terhadap Notaris. Namun ternyata disisi yang lain batasan-batasan seperti itu dijadikan dasar untuk memidanakan Notaris dengan dasar Notaris telah membuat surat palsu atau memalsukan akta (Pasal 263, 264 dan 266 KUHP) dengan kualifikasi sebagai suatu tindak pidana yang dilakukan oleh Notaris. Hal ini dapat terjadi sebagai akibat tidak diaturnya penjatuhan sanksi pidana terhadap notaris yang melanggar kewajiban dan larangan UUJN. Padahal jika diperhatikan kembali dalam Peraturan Jabatan Notaris (PJN), suatu peraturan yang menjadi cikal bakal UUJN, di dalamnya terdapat sanksi pidana terhadap Notaris yang melanggar ketentuan pasal-pasal dalam PJN, meskipun hanya mencantumkan sanksi pidana berupa denda dan bukan sanksi pidana kurungan atau penjara.

Konsekuensi ketiadaan pengaturan tentang mekanisme penjatuhan sanksi hukum (sesuai hukum acara) baik itu sanksi perdata maupun sanksi pidana terhadap Notaris yang melanggar kewajiban dan larangan UUJN, berakibat timbulnya ketidakpastian hukum (rechtsonzekerheid) atau ketidakpastian peraturan perundang-undangan di masyarakat. Dampak yang lebih jauh lagi akan berakibat pada kekacauan hukum, dalam arti bahwa selama tidak diatur berarti boleh, selama belum ada tata cara yang jelas dan diatur berarti bukan tidak boleh. Kondisi seperti ini menyebabkan kebingungan dalam masyarakat mengenai aturan apa yang harus dipakai atau diterapkan. ${ }^{6}$ Apabila hal ini terjadi, maka hak Notaris dan para pihak yang terkait tidak memperoleh pemeriksaan yang adil serta tidak memberikan perlindungan hukum.
Berdasarkan pemaparan diatas, maka menarik bagi penulis untuk menulis penelitian yang dapat diangkat sebagai karya ilmiah dalam bentuk tesis dengan judul "Sanksi Hukum Terhadap Notaris Yang Melanggar Kewajiban Dan Larangan Undang-Undang Jabatan Notaris".

\subsection{Rumusan Masalah}

Berdasarkan latar belakang masalah di atas, maka dapat dirumuskan masalahnya sebagai berikut:

1. Bagaimanakah pengaturan sanksi hukum terhadap Notaris yang melanggar kewajiban dan larangan UUJN?

2. Bagaimanakah mekanisme penjatuhan sanksi hukum (sesuai hukum acara) terhadap Notaris yang melanggar kewajiban dan larangan UUJN?

\subsection{Tujuan Penelitian}

\section{a. Tujuan Umum}

Secara umum penelitian tesis ini bertujuan untuk pengembangan ilmu hukum khususnya dalam bidang Hukum Kenotariatan. Penelitian ini mengkaji mengenai pemahaman tentang pengaturan dan mekanisme penjatuhan sanksi hukum (sesuai hukum acara) terhadap Notaris yang melanggar kewajiban dan larangan Undang-Undang Jabatan Notaris.

b. Tujuan Khusus

1. Untuk mendiskripsikan dan menganalisa secara mendalam mengenai pengaturan sanksi hukum terhadap Notaris yang melanggar kewajiban dan larangan UUJN.

2. Untuk mendiskripsikan dan menganalisa secara mendalam mengenai mekanisme penjatuhan sanksi hukum (sesuai hukum acara) terhadap Notaris yang melanggar kewajiban dan larangan UUJN.

\subsection{Landasan Teoritis}

Asas-asas hukum, konsep hukum dan teoriteori hukum dalam landasan teoritis ini yang digunakan untuk membahas masalah penelitian adalah:

1. Asas Kepastian Hukum

2. Asas Praduga Sah

3. Konsep Perlindungan Hukum

4. Teori Ketaatan Hukum dan Sanksi

5. Teori Kebijakan Hukum Pidana

6. Teori Pembuktian

7. Teori Legislasi

\subsection{Metode Penelitian}

\subsubsection{Jenis Penelitian}

Penelitian yang dilakukan dalam tesis ini merupakan penelitian hukum normatif. Penelitian hukum normatif merupakan

6 Soerjono Soekanto dan Purnadi Purbacaraka,Op.Cit.,h.89 
penelitian yang melihat hukum sebagai seperangkat norma (kaidah). ${ }^{7}$

\subsubsection{Jenis Pendekatan}

Jenis pendekatan yang digunakan dalam penelitian ini adalah pendekatan peraturan perundang-undangan (The Statute Approach), dan pendekatan analisis konsep hukum (Analitical \& Conseptual Approach). ${ }^{8}$

\subsubsection{Sumber Bahan Hukum}

Sumber bahan hukum dalam penelitian ini bersumber dari kepustakaan yang terdiri dari bahan hukum primer, bahan hukum sekunder, dan tertier.

\subsubsection{Teknik Pengumpulan Bahan Hukum}

Teknik pengumpulan bahan hukum yang digunakan dalam penelitian ini adalah dengan menggunakan metoda bola salju (snowball method). ${ }^{9}$ Adapun yang dimaksud dengan metode bola salju adalah menggelinding terus menerus yang mengacu kepada peraturan perundang-undangan dan buku-buku hukum dalam daftar pustaka. Pengumpulan bahan hukum primer, bahan hukum sekunder dan tertier diinventarisasi dan diklasifikasi secara sistematis sesuai dengan permasalahan yang dibahas dalam penelitian ini.

\subsubsection{Teknik Analisis Bahan Hukum}

Penelitian ini menggunakan teknik deskripsi dan tehnik penemuan hukum (Rechtsvinding). Teknik deskripsi adalah menguraikan adanya suatu kondisi atau posisi dari proposisi-proposisi hukum atau non hukum. ${ }^{10}$ Penemuan hukum menurut Sudikno Mertokusumo adalah proses penemuan hukum oleh hakim atau aparat penegak hukum lainnya yang ditugaskan untuk menerapkan peraturan hukum umum pada peristiwa yang konkret.

\section{Tinjauan Umum Notaris Dan \\ Sanksi}

\subsection{Tinjauan Umum Notaris}

\subsubsection{Sejarah Singkat Notariat}

Sejarah Notariat di Indonesia tidak terlepas dari sejarah lembaga notariat di Negara-negara Eropa pada umumnya dan negeri Belanda pada khususnya. ${ }^{11}$ Perjalanan Notaris di Indonesia mengalami perkembangan

${ }^{7}$ L.J.Van Apeldoorn, 2001, Pengantar Ilmu Hukum, Pradnya Paramita, Jakarta, h.18.

${ }^{8}$ Zainudin Ali, 2010, Metode Penelitian Hukum, Sinar Grafika, Jakarta, h.24.

${ }^{9}$ I Made Wahyu Chandra Satriana, 2013, Kebijakan Formulasi Keadilan Restoratif Dalam Sistem Peradilan Pidana (tesis), Program Studi Magister (S2) Ilmu Hukum Universitas Udayana, Denpasar.

${ }^{10}$ M. Iqbal Hasan, 2002, Pokok-Pokok Materi Metode Penelitian dan Aplikasinya, Cet. I, Ghalia Indonesia, Jakarta, h.43.

${ }^{11}$ G.H.S.Lumban Tobing, 1983, Peraturan Jabatan Notaris, Cetakan ketiga, Penerbit Erlangga, Jogjakarta, h.10. sesuai dengan perkembangan Negara dan bangsa Indonesia. Sejarah kontemporer Indonesia mencatat bahwa pada era Reformasi terjadi perubahan lembaga notariat yang cukup signifikan. Perubahan tersebut ditandai dengan berhasilnya pemerintahan orde reformasi mengundangkan Undang-Undang Nomor 30 Tahun 2004 tentang Undang-undang Jabatan Notaris (UUJN). UUJN merupakan pengganti PJN (Staatblad 1860- 3) dan Reglement op het Notarist ambt in Indonesia (Staatblad 1860- 3) yang merupakan peraturan pemerintah kolonial Belanda. ${ }^{12}$ UUJN mulai berlaku di Indonesia pada tanggal 6 Oktober 2004 dan terakhir diperbaharui dengan diundangkannya UndangUndang Nomor 2 tahun 2014 tentang Jabatan Notaris pada tanggal 15 Januari 2014 di Jakarta.

\subsubsection{Pengertian Notaris}

Pasal 1 angka 1 Undang- UUJN menyatakan bahwa: Notaris adalah pejabat umum yang berwenang untuk membuat akta autentik dan memiliki kewenangan lainnya sebagaimana dimaksud dalam undang-undang ini atau berdasarkan undang-undang lainnya. Istilah Pejabat Umum ${ }^{13}$ merupakan terjemahan dari istilah openbare ambtenaren yang terdapat dalam Pasal $1 \mathrm{PJN}^{14}$ dan Pasal 186 Burgerlijk Wetboek (BW). ${ }^{15}$ Notaris bukanlah Pegawai Negeri, walaupun Notaris diangkat dan disumpah oleh pemerintah. Notaris tidak menerima gaji, tetapi menerima honorarium sebagai penghargaan atas jasa yang telah diberikan kepada masyarakat. ${ }^{16}$ Notaris adalah pejabat umum sebagaimana dimaksud Pasal 1868 KUHPerdata.

\subsubsection{Tugas dan Kewenangan Notaris}

Pasal 1 Angka 1 UUJN selain menguraikan mengenai pengertian Notaris, juga menyebutkan kewenangan Notaris, yaitu sebagai pejabat umum yang berwenang untuk

${ }^{12}$ Abdul Ghofur Anshori, 2010, Lembaga Kenotariatan Indonesia, UII Press, Jogjakarta, h.13.

${ }^{13}$ Mahkamah Konstitusi Republik Indonesia (MKRI) dengan putusan nomor 009014/PUU-111/2005, tanggal 13 September 2005, mengistilahkan pejabat umum sebagai public officials.

${ }^{14}$ Istilah Openbare Ambtenaren yang terdapat dalam Art.1 dalam Reglement op het Notaris Ambt in Indonesia (Ord.Van Jan.1860). S.1860-3, diterjemahkan menjadi Pejabat Umum oleh G.H.S. Lumban Tobing. Op.Cit., h.5.

${ }^{15}$ Istilah Openbare Ambtenaren yang terdapat dalam Pasal 186 BW diterjemahkan menjadi Pejabat Umum oleh R. Subekti dan R. Tjitrosudibio, 1983, Kitab Undang-Undang Hukum Perdata, Pradnya Paramita, Jakarta, h.7.

${ }^{16}$ Komar Andasasmita, 1981, Notaris dengan Sejarah, Peranan, Tugas Kewajiban, Rahasia Jabatannya, Sumur, Bandung, h.45. 
membuat akta otentik dan kewenangan lainnya sebagaimana dimaksud dalam Pasal 15 UUJN.

\subsection{Kewajiban dan Larangan Notaris}

Kewajiban Notaris menurut UUJN, dalam menjalankan jabatannya diatur dalam Pasal 16. Kewajiban-kewajiban Notaris disertai pula dengan larangan-larangan bagi Notaris dalam menjalankan jabatannya sebagaimana dinyatakan dalam Pasal 17 UUJN.

\subsection{Tinjauan Umum Sanksi}

\subsubsection{Pengertian Sanksi}

Sudikno Mertokusumo menyatakan "Sanksi tidak lain merupakan reaksi, akibat, atau konsekuensi pelanggaran kaidah sosial. ${ }^{17,}$ Dari definisi tersebut dapat dilihat bahwa sanksi mengandung unsur-unsur: 1) Sanksi merupakan reaksi, akibat, atau konsekuensi dari pelanggaran kaidah sosial (baik kaidah hukum maupun kaidah nonhukum) dan 2) Sanksi merupakan kekuasaan untuk memaksakan ditaatinya kaidah sosial tertentu.

\subsubsection{Pengertian Sanksi Hukum}

Sanksi hukum diperlukan agar anggota masyarakat mematuhi hukum. Sanksi hukum diartikan sebagai sarana untuk melindungi kepentingan individu ataupun badan (kemerdekaan, jiwa, harta, hewan, badan) dengan jalan mengancam hukuman sebagai sanksi terhadap pelanggaran hukum. ${ }^{18}$ Sanksi hukum dipertahankan oleh pemerintah untuk menjadikan anggota masyarakat mematuhi hukum sebagaimana dikehendaki oleh peraturan.

\subsubsection{Jenis-Jenis Sanksi Hukum}

\subsubsection{Sanksi Perdata}

Sanksi keperdataan adalah sanksi yang dijatuhkan terhadap kesalahan yang terjadi karena wanprestasi, atau perbuatan melawan hukum (onrechtmatige daad). Dalam konteks pembahasan ini adalah perbuatan melawan hukum yang dilakukan Notaris karena melanggar kewajiban dan larangan UUJN. Unsur dari perbuatan melawan hukum disini yaitu adanya suatu perbuatan yang dilakukan secara melawan hukum, adanya kesalahan dan adanya kerugian yang ditimbulkan. Perbuatan melawan hukum disini diartikan luas, yaitu suatu perbuatan tidak saja melanggar undangundang, tetapi juga melanggar kepatutan, kesusilaan atau hak orang lain dan menimbulkan kerugian.

\subsubsection{Sanksi Administratif}

Sanksi dalam hukum administrasi yaitu alat kekuasaan yang bersifat hukum publik yang dapat digunakan oleh pemerintah sebagai reaksi atas ketidakpatuhan terhadap kewajiban yang

17 Achmad Ali, 2011, Menguak Tabir Hukum, Bogor, Ghalia Indonesia, h. 42

${ }^{18}$ M.H. Tirtaamidjaya, 1995, Pokok-Pokok Hukum Pidana, Penerbit Fasco, Jakarta, h.15. terdapat dalam norma administrasi negara. ${ }^{19}$ Menurut Philipus M. Hadjon ${ }^{20}$ dan H.D.Van Wijk/ Willem Konijnenbelt ${ }^{21}$ sanksi administrasi meliputi: paksaan pemerintah (bestuurdwang), penarikan kembali keputusan (ketetapan) yang menguntungkan (izin pembayaran, subsidi), pengenaan denda administratif dan pengenaan uang paksa oleh pemerintah (dwangsom).

\subsubsection{Sanksi Pidana}

Menurut Herbert L.Packer, sanksi pidana adalah suatu alat atau sarana terbaik yang tersedia, yang dimiliki untuk menghadapi kejahatan-kejahatan atau bahaya besar serta untuk menghadapi ancaman-ancaman. ${ }^{22}$ Sanksi pidana diatur dalam Pasal 10 KUHP, yang terdiri atas: Pidana pokok (pidana mati, pidana penjara dan pidana kurungan dan pidana denda) dan Pidana tambahan (Pencabutan hak-hak tertentu; Perampasan barang-barang tertentu dan Pengumuman putusan hakim).

III. Pengaturan Sanksi Hukum Terhadap Notaris Yang Melanggar Kewajiban Dan Larangan Undang-Undang Jabatan Notaris

\subsection{Hakikat Pengaturan Sanksi Hukum Dalam UUJN}

Sanksi merupakan alat pemaksa, selain hukuman, juga untuk mentaati ketetapan yang ditentukan dalam peraturan atau perjanjian. Sanksi pada hakikatnya merupakan instrumen yuridis yang biasanya diberikan apabila kewajiban-kewajiban atau laranganlarangan yang ada dalam ketentuan hukum telah dilanggar, dan di balik pintu ketentuan perintah dan larangan (geen verboden) tersedia sanksi untuk memaksa kepatuhan.

\subsection{Jenis-Jenis Sanksi Hukum Dalam UUJN}

\subsubsection{Sanksi Perdata}

Sanksi perdata terhadap Notaris yang melanggar pasal-pasal tentang kewajiban dan larangan dalam UUJN yaitu: Pasal 16 ayat (1) huruf m, Pasal 41 dengan menunjuk kepada Pasal 38, Pasal 39 dan Pasal 40, Pasal 48, Pasal 49, Pasal 50 dan Pasal 51. Sanksi perdata sebagaimana dijelaskan pasal-pasal diatas adalah berupa penggantian biaya, ganti rugi dan bunga merupakan akibat yang akan diterima Notaris dari gugatan para penghadap apabila akta bersangkutan hanya mempunyai kekuatan pembuktian sebagai akta dibawah tangan. Penggantian biaya, ganti rugi atau bunga dapat digugat terhadap Notaris, namun terlebih

${ }^{19}$ Ridwan HR., 2003, Hukum Administrasi Negara, UII Press, Jogjakarta, h. 235.

${ }^{20}$ Philipus M.Hadjon, dkk, Op.Cit., h.245.

${ }^{21}$ H.D.Van Wijk/ Willem Konijnenbelt, 1990, Hoolfdstukken van Administratief Recht, Uitgeverij Lemma BW, Utrecht, h.330-345.

${ }^{22}$ Herbert L. Packer, 1967, The Limits of the Criminal Sanction, Stanford California University Press, h.344-346. 
dahulu harus dapat dijelaskan batasan-batasan atau pasal-pasal manakah yang telah dilanggar oleh Notaris dan harus dengan mendasarkan adanya suatu hubungan hukum antara Notaris dengan para pihak.

\subsubsection{Batasan Akta Notaris yang Mempunyai Kekuatan Pembuktian di Bawah Tangan}

Pasal 1869 BW menentukan batasan akta Notaris yang mempunyai kekuatan pembuktian sebagai akta di bawah tangan dapat terjadi jika memenuhi ketentuan karena: a) tidak berwenangnya pejabat umum yang bersangkutan; b) tidak mampunya pejabat umum yang bersangkutan; c) cacat dalam bentuknya. Akta yang dibuat di bawah tangan mempunyai kekuatan pembuktian yang sah jika pembuat akta tersebut mengakui isi akta serta tanda tangan yang ada pada akta tersebut. Penurunan status kekuatan alat bukti akta Notaris ini, dapat terjadi apabila dalam pembuatannya terjadi pelanggaran terhadap ketentuan persyaratan berdasarkan hukum yang berlaku yaitu Notaris telah melakukan pelanggaran terhadap kewajiban dan larangan UUJN. Contohnya Notaris membuat akta-akta yang tidak sesuai dengan fakta, akta tersebut tidak dibacakan oleh Notaris kepada para penghadap dan saksi-saksi, atau akta tidak ditandatangani pada tanggal yang sama oleh para penghadap.

Apabila hal tersebut dilakukan oleh Notaris, maka ada syarat formal dalam pembuatan akta yang tidak terpenuhi, sehingga akta yang dibuat oleh Notaris hanya mempunyai kekuatan pembuktian sebagai akta di bawah tangan, bila timbul kerugian bagi para pihak, Notaris dapat digugat melakukan perbuatan melawan hukum (onrechtmatige daad) sebagaimana diatur di dalam Pasal 1365 KUHPerdata

\subsubsection{Hubungan Hukum Notaris dengan Para Penghadap Dalam Menentukan Sanksi Perdata.}

Pada dasarnya hubungan hukum antara Notaris dan para penghadap yang membuat akta di hadapan atau oleh Notaris tidak dapat ditentukan pada awal Notaris dan para penghadap berhubungan, karena pada saat itu belum terjadi permasalahan apapun. Untuk menentukan bentuk hubungan hukum antara Notaris dengan para penghadap harus dikaitkan dengan ketentuan pasal 1869 BW. Kemudian hal ini dapat dijadikan dasar untuk menggugat Notaris sebagai suatu perbuatan melawan hukum karena:

a. Notaris tidak berwenang membuat akta yang bersangkutan;

b. tidak mampunya Notaris yang bersangkutan dalam membuat akta;

c. akta Notaris cacat dalam bentuknya;dan

d. kelalaian atau kesalahan Notaris yang menimbulkan kerugian kepada pihak lain.
Dengan demikian kedudukan akta Notaris yang mempunyai kekuatan pembuktian sebagai akta di bawah tangan tidak didasarkan pada akta Notaris yang tidak memenuhi syarat subjektif dan syarat objektif, tapi dalam hal:

a. Undang-undang (UUJN) telah menentukan sendiri ketentuan syarat akta Notaris yang mempunyai kekuatan pembuktian sebagai akta di bawah tangan yaitu tidak memenuhi syarat eksternal.

b. Notaris tidak cermat, tidak teliti, dan tidak tepat dalam menerapkan aturan hukum yang berkaitan dengan pelaksanaan tugas jabatan Notaris berdasarkan UUJN, juga dalam menerapkan aturan hukum yang berkaitan dengan isi akta.

Tuntutan terhadap Notaris dalam bentuk penggantian biaya, ganti rugi, dan bunga sebagai akibat akta Notaris mempunyai kekuatan pembuktian sebagai akta di bawah tangan berdasarkan adanya:

a. Hubungan hukum yang khas antara Notaris dengan para penghadap dengan bentuk sebagai perbuatan melawan hukum.

b. Ketidakcermatan, ketidaktelitian, dan ketidaktepatan dalam: (1) Teknik administratif membuat akta berdasarkan UUJN; (2) Penerapan berbagai aturan yang tertuang dalam akta yang bersangkutan untuk para penghadap, yang tidak didasarkan pada kemampuan menguasai keilmuan bidang Notaris secara khusus dan hukum pada umumnya.

Sebelum Notaris dijatuhi sanksi perdata berupa penggantian biaya, ganti rugi, dan bunga, maka terlebih dahulu harus dapat dibuktikan bahwa (a) ada kerugian yang timbul; (b) ada hubungan kausal atau sebab akibat antara timbulnya kerugian dan perbuatan yang melanggar norma yang dilakukan oleh para pihak; dan (c) pelanggaran (perbuatan) atau kelalaian tersebut disebabkan kesalahan yang dapat dipertanggungjawabkan kepada Notaris yang bersangkutan.

\subsubsection{Sanksi administratif}

Sanksi administratif yang dijatuhkan terhadap Notaris yang melanggar kewajiban dan larangan UUJN terdiri atas: peringatan tertulis, pemberhentian sementara, pemberhentian dengan hormat dan pemberhentian dengan tidak hormat. Sanksi administrasi dapat dijatuhkan terhadap Notaris karena melanggar pasal-pasal sebagai berikut: Pasal 7 ayat (1), Pasal 16, Pasal 17, Pasal 19, Pasal 32, Pasal 37, Pasal 54, Pasal 58 dan Pasal 59.

Pengaturan sanksi administratif dalam UUJN yaitu dengan menempatkan teguran tertulis pada urutan pertama pemberian sanksi, 
merupakan suatu peringatan kepada Notaris dari Majelis Pengawas yang jika tidak dipenuhi ditindaklanjuti dengan pemberhentian sementara, jika sanksi seperti ini tidak dipenuhi juga oleh Notaris yang bersangkutan, maka dapat dijatuhi sanksi berikutnya secara berjenjang. Penerapan ketentuan pasal di atas tentunya harus memperhatikan tingkat berat ringannya pelanggaran yang dilakukan Notaris, dalam arti bahwa penerapan sanksi tersebut sifatnya gradual atau berjenjang.

\subsubsection{Sanksi Lainnya Dan Kumulasi Sanksi}

Pengertian sanksi lainnya dalam pembahasan ini adalah sanksi kode etik dan sanksi pidana yang tidak diatur dalam UUJN. Notaris dapat dikenakan sanksi kode etik karena melanggar larangan sebagaimana diatur dalam Pasal 4 Kode Etik Notaris. Pengaturan tentang sanksi dalam Kode Etik Notaris dapat ditemukan di dalam Pasal 6. Sanksi yang dapat dikenakan terhadap anggota Ikatan Notaris Indonesia (I.N.I), yang melakukan pelanggaran Kode Etik dapat berupa: teguran, peringatan, skorsing (pemecatan sementara) dari keanggotaan perkumpulan dan onzetting (pemecatan) dari keanggotaan perkumpulan : ${ }^{23}$

Sanksi Pidana terhadap Notaris harus dilihat dalam rangka menjalankan tugas jabatan Notaris, artinya dalam pembuatan atau prosedur pembuatan akta harus berdasarkan kepada UUJN. Jika semua tata cara pembuatan akta sudah ditempuh suatu hal yang tidak mungkin seorang Notaris secara sengaja bersama-sama atau membantu penghadap secara sadar membuat akta untuk melakukan suatu tindak pidana. Sanksi Pidana terhadap Notaris tunduk terhadap ketentuan pidana umum, yaitu KUHP. UUJN tidak mengatur mengenai tindak pidana khusus untuk Notaris. Dengan adanya lebih dari satu jenis sanksi yang dapat dijatuhkan terhadap Notaris, berkaitan dengan kumulasi sanksi terhadap Notaris. Dalam kaidah peraturan perundang-undangan di bidang Hukum Administrasi sering tidak hanya memuat satu macam sanksi, tetapi terdapat beberapa sanksi yang diberlakukan secara kumulasi, adakalanya suatu ketentuan peraturan perundang-undangan tidak hanya mengancam pelanggarnya dengan sanksi pidana, tetapi pada saat yang sama mengancamnya dengan sanksi administrasi. ${ }^{24}$

UUJN tidak mengatur kumulasi sanksi sebagaimana tersebut di atas. UUJN hanya mengatur sanksi perdata dan sanksi administrasi, dan kedua sanksi ini tidak dapat dikumulasikan dan tidak dapat dilakukan secara bersama-sama, karena masing-masing sanksi tersebut dapat dijatuhkan karena melakukan jenis pelanggaran yang berbeda, demikian pula

${ }^{23}$ Abdul Ghofur Anshori, 2009, Lembaga Kenotariatan Indonesia, Perspektif Hukum dan Etika, UII Press, Yogyakarta, h.70, h.71.

${ }^{24}$ Philipus M.Hadjon, dkk., Op.Cit. h.263. dengan sanksi yang lainnya, yakni sanksi pidana dan kode etik. Sanksi- sanksi tersebut berdiri sendiri yang dapat dijatuhkan oleh instansi yang diberikan kewenangan untuk itu.

\subsubsection{Batasan Akta Notaris Yang Dapat Dijadikan Dasar Memidanakan Notaris}

Notaris dalam melakukan suatu pelanggaran sebenarnya dapat dijatuhi sanksi administrasi atau perdata atau kode etik jabatan Notaris, tapi kemudian ditarik atau dikualifikasikan sebagai suatu tindak pidana yang dilakukan oleh Notaris. Pengkualifikasian tersebut berkaitan dengan aspek-aspek seperti:

a. tidak menjamin kepastian hari, tanggal, bulan, tahun dan waktu menghadap;

b. siapa pihak (orang) yang menghadap notaris;

c. tidak berwenangnya tanda tangan yang menghadap;

d. ditemukan salinan akta tidak sesuai dengan minuta akta;

e. ada salinan akta, tanpa dibuat minuta akta; dan

f. minuta akta tidak ditandatangani secara lengkap, tapi salinan minuta akta dikeluarkan.

Aspek-aspek tersebut merupakan batasanbatasan yang jika dapat dibuktikan dapat dijadikan dasar untuk dijatuhkan sanksi administratif dan sanksi perdata terhadap Notaris. Namun ternyata disisi yang lain batasan-batasan seperti itu dijadikan dasar untuk memidanakan Notaris dengan dasar Notaris telah membuat surat palsu atau memalsukan akta (Pasal 263, 264 dan 266 KUHP) dengan kualifikasi sebagai suatu tindak pidana yang dilakukan oleh Notaris. Aspek lainnya yang perlu untuk dijadikan batasan dalam hal pelanggaran oleh Notaris harus diukur berdasarkan UUJN artinya apakah perbuatan yang dilakukan oleh Notaris melanggar pasal-pasal tertentu dalam UUJN, karena ada kemungkinan menurut UUJN bahwa akta yang bersangkutan telah sesuai dengan UUJN, tetapi menurut pihak penyidik perbuatan tersebut merupakan suatu tindak pidana. Dengan demikian sebelum melakukan penyidikan lebih lanjut, lebih baik meminta pendapat mereka yang mengetahui dengan pasti mengenai hal tersebut, yaitu dari Organisasi Jabatan Notaris.

Dengan demikian pemidanaan terhadap Notaris dapat saja dilakukan dengan batasan, jika: $^{25}$

1. Ada tindakan hukum dari Notaris terhadap aspek formal akta yang sengaja, penuh kesadaran dan keinsyafan serta direncanakan, bahwa akta yang dibuat dihadapan Notaris atau oleh Notaris bersama-sama (sepakat) untuk dijadikan

${ }^{25}$ Habib Adjie,Op.Cit.,h.124-125 
dasar untuk melakukan suatu tindak pidana;

2. Ada tindakan hukum dari Notaris dalam membuat akta dihadapan atau oleh Notaris yang jika diukur berdasarkan UUJN tidak sesuai/bertentangan dengan UUJN;

3. Tindakan Notaris tersebut tidak sesuai menurut instansi yang berwenang dalam hal ini Majelis Pengawas Notaris.

Penjatuhan sanksi pidana terhadap Notaris dapat dilakukan sepanjang batasan-batasan sebagaimana tersebut di atas dilanggar, artinya di samping memenuhi rumusan pelanggaran yang tersebut dalam UUJN dan Kode Etik Jabatan Notaris juga harus memenuhi rumusan yang tersebut dalam KUHP.

IV. Mekanisme Penjatuhan Sanksi Hukum (Sesuai Hukum Acara) Terhadap Notaris Yang Melanggar Kewajiban Dan Larangan Undang-Undang Jabatan Notaris

\subsection{Pengawasan Notaris}

Pasal 67 ayat (1) UUJN menentukan bahwa yang melakukan pengawasan terhadap Notaris adalah Menteri dalam hal ini Menteri Hukum dan Hak Asasi Manusia. Dalam melaksanakan pengawasan tersebut Menteri membentuk Majelis Pengawas (Pasal 67 ayat [2] UUJN) yang dalam pelaksanaannya dilakukan oleh Majelis Pengawas secara berjenjang yaitu Majelis Pengawas Daerah/Wilayah/Pusat sesuai dengan ketentuan dalam UUJN.

Mekanisme pengawasan terhadap Notaris saat ini dilakukan dengan 2 (dua) cara yaitu:

1) Pengawasan Internal

Pengawasan Internal adalah pengawasan yang dilakukan oleh Organisasi Notaris terhadap Notaris yang dilakukan secara berjenjang mengenai pelaksanaan kode etik yang berlaku terhadap notaris. Pengawasan Internal diatur dalam Pasal 7 Kode Etik Notaris

2) Pengawasan Eksternal

Pengawasan eksternal dilakukan oleh Menteri Hukum dan Hak Asasi Manusia, sebagaimana diamanatkan dalam pasal 67 ayat (1) dan ayat (2) UUJN, yang menyatakan bahwa Menteri berwenang melakukan pengawasan terhadap Notaris, yang dalam pelaksanaannya Menteri membentuk Majelis Pengawas Notaris (MPN). Ketentuan terhadap pengawasan Eksternal terhadap Notaris ini diatur dalam UUJN, khususnya dalam pasal 67 sampai dengan Pasal 81.

\subsection{Pemeriksaan Notaris}

Pasal 70 huruf b UUJN dan Pasal 16 ayat (1) Peraturan Menteri Hukum dan Hak Asasi Manusia Republik Indonesia Nomor M.02.PR.08.10 Tahun 2004, menegaskan bahwa Majelis Pengawas Daerah (MPD) berwenang melakukan pemeriksaan terhadap Protokol Notaris secara berkala 1 (satu) kali dalam 1 (satu) tahun atau setiap waktu yang dianggap perlu. Majelis atau Tim Pemeriksa dengan tugas semacam ini hanya ada pada MPD saja, yang merupakan tugas pemeriksaan rutin atau setiap waktu yang diperlukan dan langsung dilakukan di kantor Notaris yang bersangkutan. Tim Pemeriksa ini sifatnya insidentil (untuk pemeriksaan tahunan atau sewaktu-waktu) saja, dibentuk oleh MPD jika diperlukan.

4.3 Mekanisme Penjatuhan Sanksi Hukum (Sesuai Hukum Acara) Terhadap Notaris Yang Melanggar Kewajiban Dan Larangan Undang-Undang Jabatan Notaris

Kamus Besar Bahasa Indonesia Pusat Bahasa mendefinisikan istilah mekanisme adalah merupakan cara kerja suatu organisasi (kelompok dan sebagainya) dalam hal saling mempengaruhi untuk bekerja seperti mesin, kalau satu bergerak maka yang lain turut bergerak pula. ${ }^{26}$ Mekanisme dalam suatu kehidupan organisasi adalah merupakan proses pelaksanaan tugas dan fungsi serta kewenangan dalam suatu lembaga organisasi menurut tata aturan yang telah baku dalam organisasi itu sendiri. Kalau dikaitkan pengertian mekanisme dalam penelitian ini adalah merupakan proses pelaksanaan tugas dan fungsi serta kewenangan Pengadilan Negeri dalam menetapkan setiap tata aturan yang berlaku terkait tata cara/proses beracara baik itu dalam lingkup hukum perdata maupun hukum pidana berdasarkan hukum acara yang sedang berlaku.

\subsubsection{Di bidang Perdata}

Notaris sebagai pejabat publik yang produk akhirnya berupa akta autentik, maka dengan sendirinya produk Notaris ini terikat dalam ketentuan hukum perdata terutama dalam hukum pembuktian. Dalam praktik sering terjadi Notaris didudukkan sebagai Tergugat oleh pihak lainnya, yang merasa bahwa tindakan hukum yang tersebut dalam akta dikategorikan sebagai tindakan atau perbuatan hukum Notaris atau Notaris bersama-sama pihak lainnya yang juga tersebut dalam akta. Dalam permasalahan tersebut, apakah sudah tepat mendudukkan atau menempatkan Notaris sebagai Tergugat yang berkaitan dengan akta Notaris yang dibuat dihadapan atau oleh Notaris yang bersangkutan.

Di sisi lain dalam kaitan ini Notaris boleh saja digugat dan gugatan ini langsung ditujukan kepada Notaris sendiri (Tergugat tunggal),

$$
{ }^{26} \text { Departemen Pendidikan Nasional, }
$$
Op.Cit, h.895 
tetapi dalam hal ini ada batasannya yaitu jika para pihak yang menghadap Notaris (para pihak/penghadap yang namanya tersebut/tercantum dalam akta) menduga bahwa Notaris telah melakukan pelanggaran baik dari aspek lahiriah, formil maupun materil yang mengakibatkan akte autentik terdegradasi menjadi akta dibawah tangan, sehingga pihak yang merasa dirugikan ingin melakukan pengingkaran terhadap:

1. Hari, tanggal, bulan dan tahun menghadap.

2. Waktu (pukul) menghadap.

3. Tanda tangan yang tercantum dalam minuta akta.

4. Merasa tidak pernah menghadap.

5. Akta tidak ditandatangani dihadapan Notaris.

6. Akta tidak dibacakan.

7. Alasan lain berdasarkan formalitas akta.

Pengingkaran atas hal-hal tersebut tidak dapat dilakukan secara serta merta atau secara langsung namun harus melalui mekanisme yang sudah ditentukan yaitu dilakukan dengan cara menggugat Notaris menurut hukum acara perdata ke Pengadilan Negeri. Langkah-langkah yang harus ditempuh oleh pihak yang merasa dirugikan oleh Notaris dan menilai/ menganggap atau mengetahui bahwa akta Notaris yang diterbitkan oleh Notaris telah melanggar baik dari sisi lahiriah, formil maupun materiil dari akta otentik, maka maka pihak/ para pihak yang memberikan penilaian seperti itu harus dapat membuktikannya melalui proses peradilan (gugatan) ke Pengadilan Negeri dan meminta penggantian biaya, ganti rugi dan bunga agar dapat membuktikan penilaiannya, dengan menunjuk ketentuan atau pasal mana yang dilanggar oleh Notaris. Dengan demikian, penilaian akta Notaris yang mempunyai kekuatan pembuktian sebagai akta di bawah tangan tidak dari satu pihak saja, tapi harus dilakukan oleh atau melalui dan dibuktikan di pengadilan. ${ }^{27}$

\subsubsection{Di bidang Administratif}

Instrument penegakan hukum menurut Ten Berge meliputi pengawasan dan penegakan sanksi. Pengawasan merupakan langkah preventif untuk memkasakan kepatuhan dan penerapan sanksi merupakan langkah represif untuk memaksakan kepatuhan. ${ }^{28}$ Mekanisme penjatuhan sanksi administratif dilakukan secara langsung oleh instansi yang diberi wewenang untuk menjatuhkan sanksi tersebut. Dalam penjatuhan sanksi administratif terhadap Notaris, yang menjadi instrument pengawas yaitu Majelis Pengawas yang mengambil langkah-langkah preventif $^{29} \quad$ untuk memaksakan kepatuhan dan untuk menerapkan sanksi yang represif ${ }^{30}$ untuk memkasakan kepatuhan agar sanksi-sanksi tersebut dapat dilaksanakan.

Langkah-langkah preventif dilakukan dengan adanya pemeriksaan secara berkala 1 (satu) kali dalam setahun atau setiap waktu yang dianggap perlu untuk memeriksa ketaatan Notaris dalam menjalankan tugas jabatannya yang dilihat dari pemeriksaan protokolnya oleh Majelis Pengawas Daerah (MPD). ${ }^{31} \mathrm{MPW}$ dapat melakukan langkah represif, yaitu menjatuhkan sanksi berupa teguran tertulis dan sanksi ini bersifat final dan mengusulkan pemberian sanksi terhadap Notaris kepada Majelis Pengawas Pusat (MPP) berupa: Pemberhentian sementara 3 (tiga) bulan sampai 6 (enam) bulan; atau pemberhentian dengan tidak hormat. MPP melakukan tindakan represif berupa penjatuhan sanksi pemberhentian sementara dan mengusulkan pemberian sanksi berupa pemberhentian dengan tidak hormat kepada Menteri.

\subsubsection{Di bidang Pidana}

Kewenangan yang dimiliki Notaris yang diberikan oleh Undang-Undang Jabatan Notaris, berkaitan dengan kebenaran materiil atas akta otentiknya, jika dilakukan tanpa kehati-hatian sehingga menimbulkan kerugian, baik yang dilakukan secara sengaja maupun tidak dan apabila perbuatan tersebut memenuhi unsur-unsur tindak pidana, maka terhadap Notaris dapat dijatuhi sanksi pidana. Konsep ini menunjukkan adanya kompromi antara hukum yang bersifat tertulis sebagai suatu kebutuhan masyarakat demi kepastian hukum dan living law sebagai wujud dari pembentukan pentingnya peranan masyarakat dan orientasi hukum. ${ }^{32}$

Tidak dijatuhkannya sanksi pidana terhadap Notaris yang melanggar kewajiban dan larangan Notaris, disebabkan dalam UUJN dan kode etik Notaris tidak mengaturnya. Selain

${ }^{29}$ Pengawasan preventif bertujuan mencegah terjadinya kesalahan dan penyimpangan (pada suatu perbuatan tata usaha negara), H.M.Laica Marzuki," Penggunaan Upaya Administratif Dalam Sengketa Tata Usaha Negara," Hukum Dan Pembangunan, No.2 Tahun Xxii, April 1992, h.171.

${ }^{30}$ Pengawasan represif bertujuan guna memulihkan suatu perbuatan (tata usaha negara) yang dipandang salah, menyimpang serta merugikan pihak lain, ibid.

${ }^{31}$ Pasal 70 huruf b UUJN dan Pasal 15 Peraturan Hukum dan Hak Asasi Manusia Republik Indonesia Nomor M.02.PR.08.10 Tahun 2004.

${ }^{32}$ Lili Rasjidi dan I.B.Wyasa Putra, 1993, Hukum Sebagai Suatu Sistem, Remadja Rosdakarya, Bandung, h.79.
${ }^{27}$ Habib Adjie I, Op.Cit, h.153.

${ }^{28}$ Philipus M.Hadjon dalam B.Arief Sidharta,et al (ed),Op.Cit.,h.337 
itu Notaris yang dijatuhi pidana dianggap hanya melakukan pelanggaran kecil, sehingga hanya dijatuhi sanksi berupa sanksi perdata atau ganti rugi ataupun sanksi administrasi atau hanya berupa teguran. Dengan demikian dalam profesi Notaris, alasan-alasan ketiadaan pengaturan tentang penjatuhan sanksi pidana tersebut cenderung menjadi dasar bagi Notaris untuk melakukan pelanggaran. Menurut Muladi, upaya penanggulangan kejahatan di lingkungan profesional dapat dilakukan secara non penal dan secara penal. ${ }^{33}$ Dengan sarana non-penal, pertama-tama yang sangat diharapkan untuk dapat menangkal kejahatan-kejahatan di lingkungan profesional adalah apa yang dinamakan Professional Disciplinary Law dengan peradilan disiplinnya lalu dengan sarana penal, langkah-langkah yang hendaknya dilakukan adalah: ${ }^{34}$

1. Putusan peradilan disiplin profesi hendaknya didayagunakan

2. Untuk menilai adanya duty, breach of duty, cousation dan damage hendaknya memanfaatkan saksi ahli (expert testimony).

3. Dalam pemidanaan hendaknya menggunakan Neo-Classical Model.

4. Unsur profesional sebagai alasan pemberatan pidana (lihat Konsep Rancangan KUHP).

Menurut Abdul kadir Muhammad, upaya pencegahan terhadap kejahatan di lingkungan professional dapat dilakukan melalui upaya penal dengan cara: ${ }^{35}$

1. Memasukkan klausula penundukkan pada hukum positif undang-undang di dalam rumusan kode etik profesi. Setiap undang-undang mencantumkan secara tegas sanksi yang diancamkan kepada pelanggarnya. Dengan demikian, menjadi pertimbangan bagi warga, tidak ada jalan lain kecuali taat, jika terjadi pelanggaran berarti warga yang bersangkutan bersedia dikenakan sanksi yang cukup memberatkan dirinya. Ketegasan undang-undang ini lalu diproyeksikan kedalam rumusan kode etik profesi yang memberlakukan sanksi undangundang kepada pelanggaranya.

2. Legalisasi pengaturan kode etik profesi melalui Pengadilan Negeri setempat. Kode etik profesi adalah semacam perjanjian bersama semua anggota bahwa mereka berjanji untuk mematuhi kode etik yang

${ }^{33}$ Muladi dan Barda Nawawi Arief, 1992, Bunga Rampai Hukum Pidana, Bandung Alumni, h. 72.

$$
{ }_{35}^{34} \text { Abid }
$$

Profesi Hukum, Bandung: Citra Aditya, h. 86 telah dibuat bersama. Dalam rumusan kode etik itu dinyatakan, apabila terjadi pelanggaran kewajiban yang mana cukup diselesaikan oleh Dewan Kehormatan dan mana cukup diselesaikan oleh Pengadilan. Untuk memperoleh legalisasi Ketua Pengadilan Negeri setempat, kode etik itu disahkan dengan akta penetapan pengadilan yang berisi perintah penghukuman kepada setiap anggota untuk mematuhi kode etik itu. Jadi kekuatan berlaku dan mengikat kode etik mirip dengan akta perdamaian yang dibuat oleh hakim. Apabila ada yang melanggar kode etik, maka dengan surat perintah pengadilan memaksakan pemulihan tersebut.

Berdasarkan ketentuan sanksi yang diatur dalam UUJN, dapat dikatakan bahwa pelanggaran kode etik Notaris dapat disamakan dengan pelanggaran undang-undang, sehingga dapat dikenakan sanksi yang berasal dari undang-undang. Dalam hal ini kode etik Notaris menganut penundukkan pada undang-undang. Penegakan kode etik adalah usaha melaksanakan kode etik sebagaimana mestinya, mengawasi agar tidak terajadi pelanggaran, karena kode etik adalah bagian dari hukum positif, maka norma-norma penegakan hukum undang-undang berlaku pada penegakan kode etik. $^{36}$

Dilihat dari alternatif yang sudah dijelaskan sebelumnya maka sehingga setiap undang-undang diharapkan mencantumkan dengan tegas sanksi yang diancamkan kepada pelanggarnya. Walaupun tidak dapat diadakan sebuah perubahan ketentuan sanksi pidana dalam UUJN, tetapi KUHP dapat diterapkan terhadap Notaris yang melakukan pelanggaran pidana, jika dapat dibuktikan dipengadilan bahwa secara sengaja atau tidak sengaja Notaris bersama-sama dengan para pihak atau penghadap membuat akta dengan maksud dan tujuan untuk menguntungkan pihak atau penghadap tertentu saja atau merugikan penghadap yang lain. Bila hal ini terbukti, Notaris wajib dihukum dan KUHP secara umum dapat diterapkan terhadap Notaris yang melakukan pelanggaran sesuai dengan asas lex specialis derogate legi generali yang ditafsirkan secara a contrario (penafsiran yang dilakukan dengan cara memberikan perlawanan antara pengertian kongkrit yang dihadapi dan peristiwa yang diatur dalam undang-undang) yaitu sepanjang tidak diatur pengaturan mengenai sanksi pidana dalam UUJN secara khusus maka akan berlaku ketentuan sanksi pidana secara umum (KUHP).

Disisi lain, dapat pula dipertimbangkan, apabila bisa diselesaikan dengan cara lain yang lebih baik tanpa perlu menggunakan hukum

\begin{tabular}{|c|c|c|c|}
\hline${ }^{36}$ Muladi & dan & Barda & Nawawi \\
\hline
\end{tabular}
pidana, sebaiknya tidak perlu (ultimum 
remedium). Jan Remmelink berpendapat bahwa:

Kita harus mengakui bahwa kadar keseriusan pelaku, sifat perilaku yang merugikan atau membahayakan, termasuk situasi kondisi yang meliputi perbuatan tersebut memaksa kita menarik kesimpulan bahwa system-sistem sanksi lainnya demi alasan teknis murni, kurang bermanfaat untuk menaggulangi atau mencegah dialkukannya tindak kriminal, namun demikian pidana harus selalu tetap dipandang sebagai ultimum remedium. ${ }^{37}$

Pendapat Remmelink diatas dapat diartikan bahwa sanksi pidana masih tetap dibutuhkan namun dengan tetap memperhatikan asas ultimum remedium. Tetapi apabila dengan dijatuhkannya kepada seseorang terutama Notaris dengan hukum pidana seperti hukuman percobaan ataupun hukuman denda, pidana penjara dapat dihindari. Jika sekiranya terpaksa menggunakan pidana penjara, harus dipilih sesuai dengan kesalahan terdakwa baik ringan maupun berat agar dikemudian hari dapat memberikan pelajaran dan manfaat bagi terdakwa maupun masyarakat luas.

\section{Penutup}

\subsection{Kesimpulan}

Berdasarkan pembahasan yang telah diuraikan sebelumnya, maka dapat ditarik kesimpulan bahwa:

1. Pengaturan sanksi hukum terhadap Notaris yang melanggar kewajiban dan larangan dalam UUJN adalah :

a. Sanksi perdata diatur dalam Pasal 16 ayat (9 dan 12), Pasal 41, Pasal 44 ayat (5), Pasal 48 ayat (3), Pasal 49 ayat (4), Pasal 50 ayat (5) dan Pasal 51 ayat (4) yaitu akta autentik terdegradasi menjadi akta di bawah tangan dan dapat menjadi alasan bagi pihak yang menderita kerugian untuk menuntut penggantian biaya, ganti rugi dan bunga kepada Notaris, namun tidak mengatur tentang mekanisme pembatalan akte autentik yang terdegradasi menjadi akte dibawah tangan melalui gugatan di pengadilan.

b. Sanksi adminstratif diatur dalam Pasal 7 ayat (2), Pasal 16 ayat (11 dan 13), Pasal 17 ayat (2), Pasal 19 ayat (4), Pasal 32 ayat (4), Pasal 37 ayat (2), Pasal 54 ayat (2) dan Pasal 65A UUJN yaitu berupa Peringatan tertulis, Pemberhentian sementara, Pemberhentian dengan hormat dan Pemberhentian dengan tidak hormat.

c. Sanksi pidana tidak diatur dalam UUJN, namun terhadap Notaris dapat dikenakan sanksi pidana berdasarkan ketentuan yang ada dalam KUHP sepanjang tindakan Notaris telah memenuhi rumusan pelanggaran yang tersebut dalam UUJN dan kode etik jabatan notaris, juga harus memenuhi rumusan dalam KUHP.

${ }^{37}$ Jan Remmelink, Op.Cit.,h.27-28
2. Mekanisme penjatuhan sanksi hukum (sesuai hukum acara) terhadap Notaris yang melanggar kewajiban dan larangan dalam UUJN yaitu:

a. Mekanisme penjatuhan sanksi perdata terkait degradasi kekuatan pembuktian akta autentik menjadi berkekuatan sebagai akta dibawah tangan harus dengan pembuktian melalui proses gugatan perdata di pengadilan umum yang diajukan oleh para pihak yang namanya tersebut dalam akta dan menderita kerugian sebagai akibat dari akta tersebut. Pihak penggugat wajib membuktikan aspek lahiriah, formal dan materiil yang di langgar oleh Notaris. Jika terbukti maka Notaris dapat dibebani penggantian biaya, ganti rugi dan bunga. Hal ini dimaksudkan penilaian akta autentik yang mempunyai kekuatan pembuktian sebagai akta dibawah tangan tidak dari satu pihak saja, tetapi harus dilakukan oleh atau melalui dan dibuktikan di pengadilan.

b. Mekanisme penjatuhan sanksi administrasi terhadap Notaris dilakukan secara langsung oleh instansi yang diberi wewenang untuk menjatuhkan sanksi tersebut yaitu Majelis Pengawas, dimana proses penjatuhan sanksi dilakukan secara gradual (berjenjang) dengan memperhatikan berat ringannya pelanggaran yang dilakukan oleh Notaris.

c. Mekanisme penjatuhan sanksi pidana terhadap Notaris jika terbukti melakukan tindak pidana, maka Notaris wajib dihukum dan KUHP secara umum dapat diterapkan terhadap Notaris tersebut sesuai dengan asas lex specialis derogate legi generali yang ditafsirkan secara $a$ contrario yaitu sepanjang tidak diatur pengaturan mengenai sanksi pidana dalam UUJN secara khusus maka akan berlaku ketentuan sanksi pidana secara umum (KUHP). Adapun mekanisme/ prosedur penjatuhan sanksi pidana adalah para pihak yang dirugikan dapat mengajukan laporan/pengaduan kepada polisi terkait pelanggaran hukum yang dilakukan oleh Notaris, bila terbukti maka terhadap Notaris dapat dikenakan sanksi pidana berdasarkan putusan pengadilan yang telah mempunyai kekuatan hukum tetap yang amar putusannya menghukum Notaris untuk menjalani pidana tertentu.

\subsection{Saran}

Adapun saran yang dapat diberikan terkait penelitian ini adalah:

1. Agar pemerintah dan DPR merumuskan kembali pengaturan sanksi hukum terhadap Notaris yang melanggar kewajiban dan larangan UUJN yaitu dalam hal:

a. Perlunya perumusan tentang penjatuhan sanksi perdata khususnya mekanisme 
pembatalan akte autentik menjadi akta dibawah tangan melalui proses gugatan perdata ke pengadilan. Hal ini dimaksudkan untuk menghindarkan kemungkinan timbulnya interpretasi bahwa pembuktian terhadap akta autentik yang terdegradasi kekuatan pembuktiannya menjadi akta di bawah tangan dapat dilakukan secara sepihak tanpa harus melalui proses gugatan ke pengadilan. Oleh karena itu sebaiknya ketentuan dalam Pasal 60 Peraturan Jabatan Notaris yang termuat dalam Reglement op Het Notaris Ambt in Indonesia (Stbl. 1860:3) khususnya mengenai mekanisme pembatalan akta autentik menjadi akta dibawah tangan diberlakukan kembali dalam UUJN. Hal ini dikarenakan ketentuan tersebut masih relevan dan bahkan diperlukan demi kepastian hukum bagi Notaris dan para pihak dalam akta.

b. Perlunya perumusan tentang sanksi pidana dalam UUJN, agar ke depan profesi notaris lebih baik dan lebih disiplin serta terciptanya kepastian hukum terhadap masyarakat dan Notaris itu sendiri, dimana penjatuhan sanksi pidana merupakan upaya terakhir yang pamungkas untuk memberikan efek jera.

2. Sebaiknya Notaris dapat lebih menjaga profesionalismenya, lebih berhati-hati dan teliti serta memiliki itikad baik dalam pembuatan akta sehingga terhindar dari halhal yang berkaitan dengan sanksi hukum dan Notaris tetap dalam jalurnya melayani masyarakat dalam pembuatan akta berlandaskan pada moral dan etika tanpa melanggar peraturan profesi yang berlaku.

a) Buku

DAFTAR PUSTAKA

A.R, Putri 2011, Perlindungan Hukum Terhadap Notaris (Indikator Tugas-Tugas Jabatan Notaris yang Berimplikasi Perbuatan Pidana), PT. Softmedia, Jakarta.

Adjie, Habib 2009, Meneropong Khasanah Notaris dan PPAT Indonesia, Citra Aditya Bhakti, Bandung. Anshori, Abdul Ghofur 2010, Lembaga Kenotariatan Indonesia, UII Press, Jogjakarta.

Andasasmita, Komar 1981, Notaris dengan Sejarah, Peranan, Tugas Kewajiban, Rahasia Jabatannya, Sumur, Bandung

Ali, Achmad 2011, Menguak Tabir Hukum, Bogor, Ghalia Indonesia.

Ali,Zainudin 2010, Metode Penelitian Hukum, Sinar Grafika, Jakarta.

Iqbal Hasan, M. 2002, Pokok-Pokok Materi Metode Penelitian dan Aplikasinya, Cet. I, Ghalia Indonesia, Jakarta.

Lumban Tobing, G.H.S. 1983, Peraturan Jabatan Notaris, Cetakan ketiga, Penerbit Erlangga, Jogjakarta. Packer, Herbert L. 1967, The Limits of the Criminal Sanction, Stanford California University Press

Ridwan HR, 2003, Hukum Administrasi Negara, UII Press, Jogjakarta.

Soerjono Soekanto dan Purnadi Purbacaraka, 1993, Sendi-Sendi Ilmu Hukum dan Tata Hukum, Citra Aditya Bakti, Bandung.

Subekti, R. 2008, Hukum Pembuktian, Pradnya Paramita, Jakarta.

Tirtaamidjaya, M.H. 1995, Pokok-Pokok Hukum Pidana, Penerbit Fasco, Jakarta.

Tedjosaputro, Liliana 1994, Etika Profesi Notaris dalam Penegakan Hukum Pidana, Universitas Gadjah Mada, Jogjakarta.

Van Apeldoorn, L.J. 2001, Pengantar Ilmu Hukum, Pradnya Paramita, Jakarta.

Van Wijk/ Willem Konijnenbelt, H.D. 1990, Hoolfdstukken van Administratief Recht, Uitgeverij Lemma BW, Utrecht.

b) Peraturan perundang - undangan

Kitab Undang-Undang Hukum Perdata (Burgerlijk Wetboek, Staatsblad 1847-23, terjemahan R. Soesilo dan Pramudji R., Rhedbook Publisher, Jakarta.

Undang-Undang Nomor 30 Tahun 2004 tentang Jabatan Notaris, Lembaran Negara Republik Indonesia Tahun 2004 Nomor 117, Tambahan Lembaran Negara Republik Indonesia Nomor 4432.

Undang-Undang Nomor 12 Tahun 2011 Tentang Pembentukan Peraturan Perundang-Undangan, Lembaran Negara Republik Indonesia Tahun 2011 Nomor 82, Tambahan Lembaran Negara Republik Indonesia Nomor 5234.

Undang-Undang Republik Indonesia Nomor 2 Tahun 2014 tentang Perubahan Atas Undang Undang Nomor 30 Tahun 2004 Tentang Jabatan Notaris, Lembaran Negara Republik Indonesia Tahun 2014 Nomor 3, Tambahan Lembaran Negara Republik Indonesia Nomor 5491. 